\title{
KAJIAN PENGELOLAAN DANA KOPERASI SIMPAN PINJAM KONVENSIONAL DI KOTA SEMARANG Oleh
}

\author{
Dra. Sri Purwantini, MM,Dr.Endang Rusdianti, MM \\ dan Dr. Paulus Wardoyo, MM
}

\begin{abstract}
In accordance with the principles of cooperatives, Credit Union known as financial institution, as well as serve as an intermediary institution. Credit Unions activities include collecting deposits from members, gives loans to members, other cooperatives and or their members, as well as manage the balance of funding and lending.

Based on the study results, it is found that Credit Unions can not rely on collection of funds from the member either in the form of savings, compulsory savings, time deposits. In addition, Credit Unions are also less interested in establishing a partnership with the Bank either through the linkage program and other programs.

In an effort to balance of fund and loan portfolio, the manager of more use their experiences in the past, so that utilization is less than optimal. Weak regulation, has made the behavior of the manager of Credit Unions to act like a bank.

Keywords: Credit Union, linkage program, the behavior of managers
\end{abstract}

\section{PENDAHULUAN}

Menurut UU no 25 tahun 1992, yang dimaksud dengan Koperasi adalah badan usaha yang beranggotakan orang seoarang atau badan hukum koperasi dengan melandaskan kegiatan berdasarkan prinsip koperasi sekaligus sebagai gerakan ekonomi rakyat yang berdasarkan pada asas kekeluargaan. Selanjutnya berdasar paal 4 dari UU No 25 tahun 1992, disebutkan bahwa fungsi koperasi yaitu meliputi : 1)Membangun dan mengembangkan potensi dan kemampuan ekonomi anggota pada khususnya dan masyarakat pada umumnya untuk meningkatkan kesejahteraan ekonomi dan sosial. 2) Berperan serta secara aktif dalam upaya mempertinggi kualitas kehidupan manusia dan masyarakat, 3)Memperkokoh perekonomian rakyat sebagai dasar kekuatan dan ketahanan perekonomian nasional dengan koperasi sebagai sokogurunya.4) Berusaha untuk mewujudkan dan mengembangkan perekonomian nasional yang merupakan usaha bersama berdasarkan atas asas kekeluargaan dan demokrasi ekonomi.

Peraturan Menteri Koperasi dan Usaha Kecil dan Menengah (Permen Kop \& UMKM) Nomor 15/Per/M.KUKM/IX/2015 yang menyebutkan bahwa modal sendiri KSP terdiri dari simpanan pokok, simpanan wajib, cadangan yang disisihkan dari sisa hasil usaha, hibah dan simpanan lain yang memiliki karekteristik sama dengan simpanan wajib. Sedangkan Modal USP (Unit Simpan Pinjam) adalah modal tetap USP yang ditempatkan oleh koperasinya pada awal pendirian USP Koperasi, modal tidak tetap tambahan dari koperasi yang bersangkutan, dan cadangan yang disisihkan dari hasi usaha USP koperasi

Sementara itu Permen Kop \& UMKM Nomor 11/Per/M.KUKM/2015 tentang Petunjuk Pemupukan Modal Penyertaan bagi Koperasi, maka Koperasi dalam hal ini KSP memiliki peluang yang besar untuk menghimpun dana yang dapat 
digunakan untuk membiayai dan mengembangkan usahanya tanpa harus melanggar peraturan yang ada. Hal ini dikarenakan modal penyertaan bagi Koperasi sebagaimana yang diatur dalam peraturan di atas, dapat berasal dari Pemerintah, Anggota, Masyarakat, Badan Usaha yang berbentuk Badan Hukum seperti BUMN/BUMD atau PT milik swasta, Badan Usaha yang bukan berbadan hukum seperti $\mathrm{CV} \&$ Firma maupun penyertaan modal yang berasal dari badan hukum lainnya seperti Yayasan dls

$$
\text { Koperasi Simpan Pinjam }
$$

merupakan suatu lembaga keuangan dan termasuk sebagai lembaga intermediary, meskipun demikikan lembaga keuangan ini memiliki sifat yang khusus sesuai dengan prinsip prinsip koperasi. Menurut Permen Kop \& UMKM Nomor 15/Per/M.KUKM/2015 khususnya pasal 19 disebutkan bahwa Kegiatan usaha simpan pinjam meliputi: menghimpun simpanan dari anggota; memberikan pinjaman kepada anggota, calon anggota koperasi yang bersangkutan, koperasi lain dan atau anggotanya; dan mengelola keseimbangan sumber dana dan penyaluran pinjaman.Calon anggota koperasi sebagaimana dimaksud pada ayat (1), dalam waktu selambat-lambatnya 3 (tiga) bulan wajib menjadi anggota koperasi. Kegiatan usaha simpan pinjam dengan koperasi lain dilakukan melalui kemitraan yang dituangkan dalam perjanjian tertulis.

Koperasi memiliki berbagai macam jenis seperti koperasi serba usaha, koperasi simpan pinjam dan sebagainya, koperasi ini ada yang berbasis konvensional dan berbasis syariah. Dalam kesehariannya praktek koperasi disamping melayani anggota juga melayani masyarakat umum yang biasanya dikemas sebagai calon anggota, sehingga hal ini sangat bertentangan dengan ketentuan yang ada. Penelitian ini lebih difokuskan pada Koperasi Simpan Pinjam
Konvensional. Berdasarkan data yang ada di Dinas Koperasi \& UMKM Propinsi Jawa Tengah, jumlah di Kota Semarang adalah 104 KSP, baik yang berskala kecil, menengah maupu besar. Dinas Koperasi \& UMKM memilik kewenangan untuk melakukan pembinaan dan pengawasan terhadap Koperasi. Berkaitan dengan hal itu, dinas koperasi akan melakukan penilaian terhadap tingkat kesehatan koperasi simpan pinjam dan menggolongkannya dalam lima kategori yaitu : sehat, cukup sehat, kurang sehat, tidak sehat dan sangat tidak sehat. Kategori tadi didasarkan pada hasil perhitungan skoring dengan memperhatikan semua aspek keuangan, manajemen dll.

Dari 104 KSP yang ada, hanya 9,6 $\%$ yang berkategori sehat, sedangkan sisanya memiliki kategori di bawah itu. KSP seharusnya memberikan pelayanan dan jasa mediasi dari anggota kepada anggota, namun dalam praktek sehari-hari KSP telah melampaui kewenangannyanya dengan menawarkan dan menerima jasa simpanan dari pihak non anggota dan menyalurkan pinjaman kepada non anggota. Sepak terjang yang seperti ini adalah mirip dengan apa yang dilakukan oleh pihak perbankan, sehingga patut diduga bahwa apa yang dilakukan oleh KSP adalah merupakan pelanggaran terhadap UU Perbankan. Pengawasan dan Pembinaan yang lemah dari pihak berwenang dan aturan yang cukup longgar, terkadang dimanfaatkan oleh para pihak yang tidak bertanggungjawab untuk mendirkan KSP dan melakukan praktekpraktek yang curang dan merugikan masyarakat banyak dan menurunkan citra koperasi. KSP yang berstatus Cukup Sehat, Kurang Sehat, Tidak Sehat dan Sangat Tidak Sehat dimungkinkan terjadi karena pengurus yang kurang memiliki ketrampilan manajemen atau terbentur adanya kesulitan dalam permodalan dan pengelolaan piutang, sehingga berujung pada perkembangan usaha dan kesehatan KSP itu sendiri. 
Berangkat dari uarian di atas, maka masalah dalam penelitian ini adalah bagaimana sesungguhnya pengelolaan KSP yang ideal sehingga bisa menyeimbangkan antara kebutuhan dana serta penyalurannya dalam bentuk pinjaman, yang pada akhirnya dapat meningkatkan kesejahteraan anggota pada khususnya dan masyarakat pada umumnya.Tujuan penelitian ini adalah untuk mengkritisi praktek-praktek pengelolaan yang dilakukan oleh pengelola Koperasi Simpan Pinjam dalam menjalankan fungsinya sebagai lembaga intermediasi agar sesuai dengan prinsip-prinsip koperasi, sehinga bisa memupuk/ membangun citra sebagai koperasi yang sehat dan dipercaya oleh anggota dan masyarakat, Adapun manfaat yang diharapkan dari hasil penelitian ini dapat dijadikan sebagai masukan bagi para stakeholders tentang pengelolaan Koperasi Simpan Pinjam yang sehat dan sesuai dengan tata kelola yang baik dan jatidiri Koperasi.

\section{TELAAH PUSTAKA}

Merujuk pada pengertian koperasi seperti yang tertera dalam UU No 25 tahun 1992 tentang koperasi, maka bisa ditemukan adanya nilai - nilai dasar dalam koperasi yang meliputi : a) Koperasi sebagai badan usaha, hal ini berarti koperasi harus bisa memperlakukan dirinya seseperti badan usaha lain yang dala operasionalnya harus efisien profit oriented. Meski Koperasi harus dikelola secara professional tetapi tidak boleh keluar dari koridor koperasi yang harus bisa menyejahterakan anggotanya. b)Koperasi sebagai gerakan ekonomi rakyat, hal ini menunjukkan bahwa koperasi harus berorientasi pada raktya, sehingga aktivitasnya harus dilaksanakan oleh rakyat dan untuk rakyat, sehingga setiap pendirian koperasi harus bisa menjadi ajang kegiatan ekonomi masyarakat di sekelilingnya. Namun demikian, pemerintah harus bisa memfasilitasi gerakan ekonomi rakyat tersebut yang diujudkan melalui pembinaan dan pengawasan. c)Asas kekeluargaan, dalam pengertian ini bahwa dalam pengelolaan koperasi harus didasarkan pada prinsip kesamaan dan kebersamaan, guna mewujudkan cita-cita kehidupan yang lebih sejahtera. Prinsip kebersamaan juga

Tujuan dari manajemen aset dan mengandung pengertian kepemilikan bersama atas sumber-sumber daya dan perlakuan yang adil. d)Prinsip koperasi, ini berarti bahwa dalam menjalankan usahanya, koperasi harus mematuhi norma-norma yang dkenal dengan prinsip koperasi. Sehingga inilah yang membedakan antara usaha yang dilakukan oleh koperasi dengan badan usaha yang lainnya.

Menurut pasal 5 UU No. 25 Tahun 1992, prinsip koperasi Indonesia meliputi aspek aspek berikut : 1) Keanggotaan koperasi bersifat sukarela dan terbuka 2)Pengelolaan koperasi dilaksanakan secara demokratis. 3)Pembagian Sisa Hasil Usaha dilakukan secara adil sesuai dengan jasa masing masing anggota. 4) Pemberian balas jasa yang terbatas terhadap modal. 5)Kemandirian Berdasarkan prinsip ini, koperasi harus mampu hidup mandiri, baik dalam hal permodalan, organisasi, manajemen, maupun SDMnya.. 6) Pendidikan Perkoperasian. 7)Kerja sama antarkoperasi. Prinsip ini dimaksudkan untuk memperkokoh kedudukan koperasi dalam menghadapi persaingan dunia usaha.

liabilitas adalah untuk mengoptimalkan 
struktur pendanaan sebagaimana yang tercantum dalam neraca sehingga mampu menghasilkan laba yang maksimal dan pada saat yang bersamaan dapat meminimalkan resiko, khususnya di luar resiko pinjaman. Secara singkat, manajemen aset dan liabilitas meliputi manajemen likuiditas dan manajemen gap. Manajemen likuiditas berkaitan dengan kemampuan manajemen KSP untuk menyediakan dana yang cukup untuk melakukan pembayaran kewajiban yang segera jatuh tempo. Ini berarti manajemen likuiditas akan memiliki resiko bunga dan resiko pendanaan.Sedangkan manajemen gap adalah upaya untuk mengatasi kesenjangan atas aset yang sensitive terhadap bunga dan libilitas yang sensitive terhadap bunga. Tujuan dari manajemen gap adalah : untuk menghindari kerugian yang diakibatkan oleh gejolak suku bunga dipasaran, mengusahakan pendapatan yang maksimal dalam batas resiko tertentu, menunjang manajemen likuiditas, mengelola resiko pada batas yang aman, dan menyusun struktur neraca yang mampu menghasilkan kinerja dan

\section{Metode Penelitian}

Disain penelitian ini adalah berupa penelitian kualitatif dengan menggunakan pendekatan fenomenologi permasalahan yang diangkat merupakan permasalahan yang tidak bisa dijelaskan dan dianalisa melalui data-data statistik sehingga perlu pendekatan tertentu untuk memahaminya.

Sumber data adalah manajer koperasi simpan pinjam di kota Semarang. dan Istitusi terkait baik swasta atau pemerintah. Karena ini merupakan penelitian kualitatif, maka dalam melaksanakan proses penelitian akan digunakan research partner/informan yang akan dijadikan sebagai nara sumber. Proses memperoleh data dilakukan dengan wawancara dengan para research resiko yang wajar. Beberapa risiko aset dan liabilitas antara lain : 1)Risiko likuiditas yaitu risiko yang disebabkan oleh ketidakmampuan bank mengelola (kelebihan atau kekurangan) dana dalam kegiatan operasional. 2).Risiko suku bunga yaitu risiko yang disebabkan karena posisi reviewing asset liability tidak searah dengan perubahan suku bunga.3)Risiko nilai tukar yaitu risiko yang disebabkan oleh posisi aset \& libailitas dalam mata uang asing tidak searah dengan perubahan nilai tukar.4) Risiko portepel yaitu risiko yang disebabkan oleh struktur aset \& liabilitas tidak mendukung effisiensi operasi, seperti komposisi asset kurang menghasilkan keuntungan dan komposisi liability mengarah ke biaya tinggi. Dalam kaitan terhadap risiko portepel ini fungsi pengelolaan portepel sangat penting yaitu bagaimana mengusahakan agar komposisi dana searah dengan komposisi penggunaan dana.

partner/informan. Selain itu akan dilakukan pengamatan mengenai kondisi kehidupan sehari-hari dari research patner/informan di tempat kerja/usaha

rch partner.. Data yang muncul yang berwujud kata-kata dan bukan rangkaian angka didapatkan dalam beberapa cara, yaitu: observasi,wawancara, intisari dokumen, atau dengan cara lain yang biasanya diproses dahulu melalui cara reduksi dan trianggulasi sebelum siap digunakan (melalui pencatatan, penyuntingan, atau alihtulis), tetapi analisis kualitatif tetap menggunakan kata-kata, yang biasanya disusun ke dalam teks yang diperluas. 


\section{HASIL PEMBAHASAN}

\section{Pemupukan Ekuitas}

Menurut UU Nomor 25 tahun 1992

tentang perkoperasian, dalamt Pasal 40 bahwa modal koperasi terdiri atas modal sendiri dan modal pinjaman. Modal sendiri terdiri atas simpanan pokok, simpanan wajib, dana cadangan dan hibah. Sedangkan modal pinjaman bisa berasal dari anggota koperasi yang bersangkutan, koperasi lain, bank/lembaga keuangan, obligasi atau surat utang dan sumber-sumber lain yang sah. Menurut pasal 42 disebutkan bahwa Koperasi juga dimungkinkan untuk memupuk dana dari modal penyertaan, yang pelaksanaannya diatur dengan peraturan pemerintah. Yang menjadi pertanyaan, bagaimana sesungguhnya praktek yang dilakukan oleh kalangan pelaku Koperasi Simpan Pinjam.

Dari hasil wawancara dapat dilakukan reduksi yang dirangkum bahwa ekuitas KSP selama ini berasal dari: 1)Simpanan Pokok-dilakukan pada saat pertama kali menjadi anggota. 2)Simpanan Wajib - dibayar setiap bulan dengan jumlah tertentu. 3)Dana Cadangan yang dibentuk dengan persetujuan RAT (Rapat Anggota Tahunan). Dari hasil analisis dapat direduksi ke dalam rangkuman seperti yang tersaji sebagai berikut :

a. KSP tidak bisa mengandalkan pemupukan dana atau modal yang berasal dari para anggota yang berupa Simpanan Pokok dan Simpanan Wajib,

b. Terdapat ketidak disiplinan anggota dalam memenuhi simpanan wajib, namun pada sisi yang lain, mereka lebih cenderung banyak menuntut hak sebagai anggota.

c. Penambahan jumlah anggota sebagai salah satu upaya pemupukan ekuitas menghadapi kendala aturan baik yang berasal dari internal maupun eksternal

d. Manajer/Kepala Cabang KSP meskipun sudah memiliki sertifikasi kompetensi yang dikeluarkan oleh Lembaga Sertifikasi Profesi Koperasi, tidak bisa berbuat banyak dalam mengembangkan KSP karena segala sesuatu telah diatur oleh pengurus dan dikemas dalam keputusan RAT. Akibatnya mereka harus memiliki kreativitas guna mensiasati peraturan dan keputusan RAT.

e. Adanya perilaku dari pengurus dan pengawas koperasi, yang lebih mendominasi dan bertindak seakanakan koperasi tersebut adalah" milik pribadi", sehingga prinsip-prinsip koperasi tidak dapat berjalan seperti yang diharapkan

Selanjutnya dengan membandingkan hasil analisis dan temuan praktek sehari-hari di lapangan dengan teori yang berkaitan dengan pemupukan ekuitas koperasi yang berpijak pada UU No 25 tahun 1992 tentang Perkoperasian khususnya pasal 4 tentang fungsi dan peran koperasi serta pasal 5 tentang prisip koperasi serta Peraturan Menteri Koperasi dan Usaha Kecil dan Menengah (Permen Kop \& UMKM) Nomor 15/Per/M.KUKM/IX/2015 terlihat bahwa dalam upaya untuk meningkatkan kesejahteraan para anggota, ternyata KSP tidak bisa sepenuhnya mengandalkan pada pemupukan ekuitas, salah satu penyebabnya yaitu adanya sikap ketidak disiplinan dari anggota maupun kendala aturan.

\section{Pemenuhan Kebutuhan Modal Pinjaman}

Undang undang Koperasi, memberi ruang yang cukup bagi Koperasi untuk mengembangkan upaya untuk meningkatkan 
kesejahteraan ekonomi bagi anggota pada khususnya dan masyarakat pada umumnya. Salah satu peluang tadi adalah dimungkinkannya bagi Koperasi untuk menghimpun kebutuhan dana dalam bentuk pinjaman. Menurut UU No 25/1992 tentang perkoperasian, khususnya pasal 41 ayat 3 modal pinjaman dapat berasal dari anggota, koperasi lain dan atau anggotanya, bank dan lembaga keuangan lainnya, penerbitan surat obligasi atau surat hutang lainnya, sumber sumber lain yang sah. Disamping itu, pasal 42 ayat 1 menyebutkan bahwa koperasi diperkenankan juga untuk melakukan pemupukan modal yang berasal dari modal penyertaan

Berpijak pada peraturan di atas, untuk memenuhi kebutuhan modal kerja KSP dimungkinkan untuk menjalin kerjasama antar koperasi atau dengan memanfaatkan pinjaman Bank atau dengan menerbitkan surat berharga adalam bentuk obligasi. Pinjaman bank bisa diberikan dalam bentuk pinjaman modal kerja dengan menggunakan bunga komersial biasa atau dengan memanfaatkan pinjaman dalam bentuk kredit program seperti Kredit Usaha Rakyat/KUR atau dalam rangka linkage program yang memiliki bentuk channeling, executing maupun joint financing.

Channeling adalah merupakan pinjaman yang semua dananya berasal dari pihak Bank, KSP hanya bertindak sebagai agen yang mendapatkan fee yang berasal dari provisi dan selisih suku bunga pinjaman. Dalam executing, berarti KSP harus melakukan pembiayaan terlebih dahulu, setelah itu pinjaman yang diberikan kepada angota dan calon anggota akan diambil alih oleh pihak Bank yang menjadi mitra dalam linkage program. Bank akan memberikan penggantian yang didasarkan pada saldo pinjaman. Sedangkan dalam joint financing, pihak KSP dan Bank masingmasing memiliki share/bagian dalam pembiayaan. Besarnya share masing-masing pihak ditentukan dalam perjanjian kerjasama dan biasanya berkisar antara $20 \%$ s/d $30 \%$ untuk share KSP dan sisanya ditanggung oleh pihak Bank.

Dalam hal KSP ingin memanfaatkan penerbitan surat berharga dalam bentuk obligasi, berarti KSP harus go public. Ini berarti KSP harus menerapkan keterbukaan informasi dan mengikuti segala peraturan yang ditetapkan oleh pihak Otoritas Jasa Keuangan maupun pihak PT Bursa Efek Indonesia (BEI). KSP yang bersangkutan juga harus mengikuti pemeringkatan yang dilakukan lembaga indpenden yaitu PT Pefindo.

Dari hasil wawancara dengan para pelaku KSP dan konfirmasi terhadap para penyimpan dana di KSP dapat dilakukan analisi yang rangkumannya disajikan sebagai berikut :

a. KSP pada umumnya memiliki simpanan dan simpanan berjangka

b. Suku bunga sebagai imbalan jasa simpanan telah ditetapkan melalui RAT

c. Kedua produk tadi terlebih dahulu akan ditawarkan kepada para anggota koperasi, dan selanjutnya ditawarkan kepada masyarakat umum yang secara finansial memiliki potensi untuk menyimpan uang yang lebih di KSP

d. Untuk memenuhi peraturan yang berlaku, simpanan yang berasal dari masyarakat umum akan diperlakukan sebagai "calon anggota" dan simpanannya dikemas sebagai simpanan berjangka dengan jangka waktu 3 bulan

e. Untuk menarik menarik minat calon anggota menyimpan dananya di KSP, maka pengelola akan memberikan imbalan jasa simpanan/bunga simpanan yang kompetitif, pada umumnya suku 
bunga simpanan tersebut akan lebih tinggi dari suku bunga deposito Bank

f. Pada kejadian kejadian tertentu, KSP akan memberikan souvenir dalam bentuk parcel bagi para penyimpan dana yang dianggap loyal dengan KSP, dan ini akan dikemas sebagai biaya promosi

g. Guna menutup kebutuhan likuiditas, pinjaman antar KSP jarang dilakukan.

h. Pada umumnya KSP yang sudah "mapan" pengurusnya tidak suka mengikuti linkage program, yang merupakan program kerjama antara Bank Umum dengan KSP dalam penyaluran pinjaman kepada anggota atau calon anggota. Adapun yang menjadi alasan dikarenakan perjanjian linkage program cenderung berat sebelah dan lebih menguntungkan pihak Bank

i. Pada umumnya pengelola KSP dalam mengatasi masalah likuiditas, lebih menyukai pemberdayaan anggota atau calon anggota, daripada menggunakan pinjaman ke KSP atau Bank, hal ini dilakukan dengan alasan untuk menekan cost of fund dan tingkat suku bunga pinjaman. Disamping itu, untuk mendapatkan pinjaman Bank diperlukan adanya agunan berupa aset tidak begerak dengan nilai mencapai sekitar $150 \%$ dari plafond pinjaman

j. Calon anggota yang mau menyimpan dananya di KSP sangat dipengaruhi oleh tingginya imbalan jasa simpan/suku bunga yang terkadang masih bisa dinegosiasi, hubungan baik dengan pengelola/manajer, serta kepercayaan dengan pemiliki/pengelola

k. Dari apa yang terjadi dalam praktek serhari hari dilapangan, jika dikaitkan dengan prinsip perkoperasian yang dan peraturan yang ada, diketemukan adanya praktek yang menyimpang yang secara sadar dan sengaja dilakukan oleh para pengelola KSP. Adapun praktek menyimpang tersebut adalah berupa pensiasatan status calon anggota yang seharusnya berlaku selama 3 bulan, tetapi kenyataan selalu diperpanjang. Padahal dalam peraturan yang ada menyebutkan bahwa setelah masa 3 bulan terlewati, maka status calon tersebut harus diangkat sebagai anggota koperasi. Akibat dari perilaku tersebut, penambahan jumlah anggota koperasi cenderung stagnan.

Dari rangkuman di atas, dengan membandingkan hasil temuan dilapangan dengan peraturan yang ada, terlihat adanya praktek yang menyimpang yaitu

a) penghimpunan dana dalam bentuk simpanan atau simpanan berjangka yang seharusnya ditujukan kepada anggota atau anggota koperasi lain, ternyata dalam praktek tidak dilakukan secara konsekwen oleh KSP. Dalam praktek para pelaku KSP lebih cenderung mensiasati peraturan sebagaimana diatur dalam Permen Kop \& UMKM Nomor 15/Per/M.KUKM/IX/2015 pasal 19 ayat 2 .

b) adanya praktek "tutup mata atau praktek pembiaran" yang dilakukan oleh aparat selaku pembina dan pengawas KSP atas praktek penyiasatan peraturan. Ini menunjukkan adanya kelemahan dalam sisi peraturan yang ada, memberikan peluang praktek yang menyimpang, sehingga hal tersebut bertentangan dengan Permen Kop \& UMKM Nomor 17/Per/M.KUMK/XI/2015. 
c) penawaran suku bunga/imbalan jasa bagi para penyimpan dana yang terlebih dahulu ditetapkan oleh RAT, ternyata di lapangan terjadi adanya penyimpangan yaitu KSP menetapkan suku bunga/imbalan jasa yang lebih tinggi dari Bank, sebagai upaya untuk memenangkan persaingan. Hal tersebut masih ditambah dengan pemberian souvenir/parcel pada event tertentu. Hubungan antara penyimpan dana dengan pihak KSP lebih didasarkan pada faktor hubungan kedekatan, kepercayaan pada figure pengurus/pengelola KSP dan balas jasa yang menarik.

Bertitik tolak dari teori c.q peraturan tentang Koperasi dan praktek sehari-hari, dapat dilakukan justifikasi bahwa praktek yang menyimpang dari aturan sudah dianggap sebagai sesuatu yang wajar atau lumrah. Padahal hal dengan diterbitkannya Permen Kop \& UMKM Nomor 11/Per/M.KUKM/2015 tentang Petunjuk Pemupukan Modal Penyertaan bagi Koperasi, maka Koperasi dalam hal ini KSP memiliki peluang yang besar untuk menghimpun dana yang dapat digunakan untuk membiayai dan mengembangkan usahanya tanpa harus melanggar peraturan yang ada.

\section{Penyaluran Dana}

Menurut Permen Kop \& UMKM Nomor 15/Per/M.KUKM/2015 khususnya pasal 19 disebutkan bahwa Kegiatan usaha simpan pinjam meliputi: menghimpun simpanan dari anggota; memberikan pinjaman kepada anggota, calon anggota koperasi yang bersangkutan, koperasi lain dan atau anggotanya; dan mengelola keseimbangan sumber dana dan penyaluran pinjaman.Calon anggota koperasi sebagaimana dimaksud pada ayat (1), dalam waktu selambat- lambatnya 3 (tiga) bulan wajib menjadi anggota koperasi. Kegiatan usaha simpan pinjam dengan koperasi lain dilakukan melalui kemitraan yang dituangkan dalam perjanjian tertulis. Dari isi pasal 19 tersebut secara jelas bisa ditafsirkan bahwa sesungguhnya Koperasi hanya boleh menghimpun simpanan dari anggota, sedangkan untuk memberikan pinjaman koperasi diperbolehkan memberikan pinjaman selain kepada anggota, juga calon anggota koperasi yang bersangkutan serta koperasi lain dan atau anggotanya.

Sama seperti bisnis yang lain, di dalam manajemen pemasaran dikenal adanya Segmentasi, Targeting dan Positioning. Segementasi adalah upaya yang dilakukan oleh perusahaan untuk membagi pasar dari yang sifatnya heterogen menjadi homogen, sehingga hal ini akan memudahkan bagi perusahaan dalam memasarkan produknya, karena sekarang perusahaan bisa melayani pembeli yang memiliki kebutuhan yang sama akan suatu produk atau jasa. Langkah selanjutnya pasar yang telah tersegmentasi tersebut, akan dipilih beberapa segmen untuk dilayani atau dijadikan sebagai pasar sasaran. Adapun tujuan pemilihan segmen ini adalah untuk menyesuaikan dengan sumberdaya yang dimiliki oleh perusahaan. Sedangkan bagian yang terakhir adalah positioning, dalam pemasaran ini merupakan bagian tersulit, karena positioning tidak terkait dengan produk atau jasa, tetapi lebih berhubungan dengan benak dari calon pelanggan. Dari pengertian ini, maka "arena perang pemasaran yang sesungguhnya" justru berlangsung dalam benak pelanggan.

Jika di Bank dikenal adanya kredit, maka istilah tersebut di KSP dikenal dengan sebutan pinjaman. Pinjaman adalah penyediaan dana atau tagihan yang dapat disamakan dengan itu, berdasarkan persetujuan atau kesepakatan pinjam meminjam antara KSP /USP-Koperasi 
dengan anggotanya dan mewajibkan anggotanya untuk melunasi kewajibannya setelah jangka waktu tertentu dengan jumlah bunga imbalan atau pembagian hasil keuntungan. Dari pengertian pinjaman tersebut, dapat ditemui adanya unsur-unsur yaitu : penyediaan dana, didasarkan pada persetujuan, peminjam wajib melunasi kewajiban, memiliki jangka waktu serta ada imbalan bunga/pembagian hasil keuntungan. Dari unsur wajib melunasi kewajiban dan jangka waktu, maka dapat ditafsirkan bahwa dalam pemberian pinjaman pasti memiliki adanya unsur resiko, resiko gagal bayar yang bersifat sementara atau permanen maupun resiko yang lainnya. Sebagai lembaga intermediasi, maka resiko yang mungkin terjadi pada waktu yang akan datang , tentunya sejak awal harus diantipasi. Adapun resiko yang sejak awal dapat diprediksi yaitu berupa kemungkinan terjadinya wan prestasi yang dilakukan oleh peminjam. Merujuk pada Permen Kop \& UMKM No 20/Per/M.KUKM/IX/2008 dan Permen Kop \& UMKM No 14/Per/M.KUKM/XII/2009 tentang penilaian tingkat kesehatan KSP, disebutkan bahwa pinjaman yang diberikan oleh KSP kolektibilitas pinjamannya dikelomokkan menjadi lancar, kurang lancar, diragukan dan macet. Masing-masing tingkatan kolektibilitas memiliki kriteria sendirisendiri, salah satunya adalah jangka waktu. Dari sudut akuntansi, pengelompokkan piutang semacam disebut dengan aging schedule of recievables (umur piutang). Jika hal ini dikaitkan dengan manajemen keuangan, khususnya manajemen piutang, maka dalam pengendaliannya, KPS harus membentuk cadangan piutang ragu-ragu. Dalam bahasa perbankan disebut sebagai Pembentukan Penghapusan Aktiva Produktif (PPAP), dengan dibentuknya cadangan piutang ragu-ragu, hal ini membawa dampak yaitu berupa turunnya keuntungan usaha atau sisa hasil usaha dari KSP. Jika hal ini dilakukan oleh setiap KSP, maka dilihat dari sudut akuntansi, laporan keungan KSP akan menyajikan posisi yang wajar, sehingga bila laporan keuangan tersebut akan dipakai sebagai dasar pengambilan keputusan oleh manajemen, hal tersebut tidak akan menyesatkan.

Merujuk dari hasil wawancara dengan research partner di atas, maka dapat dilakukan analisis dan dirangkum sebagai berikut :

1. Produk jasa yang dimiliki oleh KSP adalah Simpanan dan Pinjaman

2. Cara memasarkan kedua produk tersebut dilakukan dengan tenaga pemasaran biasanya disebut sebagai Tenaga Pemasaran/Account Officer, implementasinya dilakukan door to door dan model getok tular

3. Segmen pasar pinjaman yang dilayani mayoritas berasal dari segmen yang tidak dilayani oleh Bank, sehingga pasar KSP memiliki karakteristik tersendiri/khas. Dalam pemasaran pasar ini disebut sebagai niche marketing

4. Pinjaman berjangka akan dibebani suku bunga efektif, sedang pinjaman angsuran dibebani dengan bunga flat. Dari sini terlihat adanya kemiripan antara jenis produk yang ditawarkan antara KSP dengan BPR, serta tata cara perhitungannya.

5. Dilihat dari sisi prosedur, proses penerimaan simpanan dan pembiayaan di KSP lebih sederhana, sehingga bisa memberi pelayanan yang lebih cepat dari pada BPR, sehingga ini menjadi keunggulannya.

6. Untuk mengimbangi proses yang sederhana dan cepat, maka untuk mengamankan pinjaman serta menekan tingkat resiko, pihak KSP menuntut adanya jaminan tambahan yang memiliki rasio yang lebih tinggi daripada pokok pinjaman. 
Akibatnya untuk menekan resiko yang muncul, KSP memiliki kebijakan untuk memberikan pokok pinjaman antara 50\%-60\% dari nilai taksasi agunan. Berdasarkan hal ini, bisa diduga analisis pinjaman yang dilakukan oleh KSP lebih pada pendekatan agunan (collateral approach) daripada pendekatan aliran kas (cashflow approach)

7. Dalam memasarkan produknya, KSP lebih menyasar kepada non anggota yang selanjutnya akan dikemas dengan istilah calon anggota. Hal ini dilakukan semata-mata karena pertimbangan murni bisnis untuk mencari keuntungan serta "menyejahterakan anggota "KSP.

Menurut KUH Perdata, perjanjian yang dibuat oleh para pihak akan menjadi undang-undang bagi para pembuatnya. Persoalan apakah perjanjian itu dibuat di bawah tangan atau dengan memakai akte notaris, dari sudut hukum memiliki kekuatan yang sama, permasalahan akan muncul manakala terjadi gugatan di pengadilan, adalah dalam hal pembuktian saja. Demikian dengan pengikatan jaminan, apa yang dilakukan dalam praktek sudah sesuai dengan perundang-undangan dan pelaksanaannya, untuk jaminan benda bergerak tunduk pada UU Fidusia Nomor 42 tahun 1998, sedangkan untuk jaminan benda tidak bergerak seperti tanah dan bangunan diikat dengan menggunakan UU Hak Tangungan.

Terkait dengan masalah wanprestasi dan eksekusi jaminan tambahan, nampak KSP dalam penyelesaiannya lebih cerderung memilih cara kekeluargaan dari pada kekerasan. Hal ini tentunya selaras dengan prinsip dasar Koperasi, bila dilihat dari sisi manajemen pemasaran teori customer relationship management serta segmentasi dan targeting, dimana segmen pasar yang dilayani oleh KSP sifatnya lebih spesifik dan khusus. Oleh karena itu untuk mengembangkan bisnisnya, KSP perlu mempertahankan anggota dan calon anggota, meskipun itu harus dilakukan secara selektif dengan tetap memperhatikan prinsip Koperasi, visi, misi dan tujuannya sendiri. Hal inilah yang membedakan antara bisnis koperasi dengan bisnis lainnya

Menghadapi pinjaman bermasalah, khususnya kategori diragukan, umumnya lembaga keuangan akan berupaya untuk melakukan penyelamatan pinjaman/kredit. Tindakan ini dilakukan untuk meminimalkan resiko yang harus dihadapi oleh lembaga keuangan tersebut. Bentukbentuk upaya penyelematan pinjaman/kredit biasanya dilakukan dengan cara rescheduling/penjadwalan ulang ini ditempuh dengan cara memperpanjang jangka waktu pelunasan, jumlah pembayaran angsuran dan atau jumlah pembayaran bunga, restructuring dilakukan dengan cara penataan kembali syarat-syarat pinjaman misal dengan penghapusan tunggakan, penurunan suku bunga, penambahan pokok hutang, atau dengan penyertaan sementara, sedangkan reconditioning dilakukan dengan cara melakukan perubahan syarat-syarat pinjaman atau persyaratan baru.

Upaya penyelematan pinjaman bermasalah umumnya dilakukan jika usaha yang dimiliki peminjam masih memiliki prospek yang baik di waktu yang akan datang, atau manakala pihak peminjam memiliki itikad baik dan bertindak kooperatif.

Merujuk data yang dikumpulkan dapat dilakukan reduksi dan analisis seperti yang tersebut di bawah ini:

1. Belum ada kesamaan tentang batasan rasio pinjaman bermasalah yang berlaku bagi KSP, hal ini dikarenakan belum adanya peraturan yang mengakomodir hal tersebut.

2. Pembentukan cadangan piutang ragu-ragu di KSP sepenuhnya 
menjadi

wewenang

pengurus/pengelola dan belum

memiliki aturan yang baku, sehingga

semuanya didasarkan pada

pengalaman pengelola/ manajemen

di waktu lalu

3. Karena rasio pinjaman bermasalah dan pembentukan cadangan piutang ragu-ragu belum dibakukan, maka memunculkan adanya perbedaan sudut pandang dari pengelola, sehingga hal ini menimbulkan adanya celah yang bisa disiasati oleh para pelaku KSP

4. Dengan pertimbangan kepraktisan, dalam melakukan penyelamatan pinjaman, pengelola KSP cenderung

\section{Manajemen Aset dan Liabilitas Koperasi Simpan Pinjam}

Kegiatan usaha simpan pinjam yang dilakukan oleh Koperasi adalah mirip dengan kegiatan Bank atau Lembaga Keuangan lainnya . Sehingga dengan demikian KSP juga dapat dipertimbangkan sebagai lembaga intermediasi, yang berfungsi menghimpun dana dari pihak yang kelebihan dan menyalurkannya ke pihak yang kekurangan dana atau yang membutuhkan. Namun demikian, KSP tidak boleh meninggalkan jatidirinya sebagai koperasi yang memiliki prinsip dari anggota, oleh anggota dan untuk anggota.

Merujuk pada fungsi tersebut, maka pengelola KSP perlu memahami seluk beluk tentang manajemen aset dan liabilitas. Tujuan dari manajemen aset dan liabilitas adalah untuk mengoptimalkan struktur pendanaan sebagaimana yang tercantum dalam neraca sehingga mampu menghasilkan laba yang maksimal dan pada saat yang bersamaan dapat meminimalkan resiko, khususnya di luar resiko pinjaman. Secara singkat, manajemen aset dan liabilitas meliputi manajemen likuiditas dan manajemen gap. Manajemen likuiditas

lebih suka memakai $\begin{array}{r}\text { model } \\ \text { penjadwalan ulang }\end{array}$
$\begin{aligned} & \text { dengan } \\ & \text { mengkapitalisir }\end{aligned}$
$\begin{aligned} & \text { semua } \\ & \text { dibayar. }\end{aligned}$

Dari sudut pandang akuntansi, pembentukan cadangan piutang ragu-ragu yang tidak seragam, menyebabkan angka -angka yang disajikan di laporan keuangan menjadi kurang valid atau laporan keuangan menyajikan data yang over stated, sehingga ini dapat menyesatkan bagi para pengguna laporan keuangan tersebut.

berkaitan dengan kemampuan manajemen KSP untuk menyediakan dana yang cukup untuk melakukan pembayaran kewajiban yang segera jatuh tempo. Ini berarti manajemen likuiditas akan memiliki resiko bunga dan resiko pendanaan.Sedangkan manajemen gap adalah upaya untuk mengatasi kesenjangan atas aset yang sensitive terhadap bunga dan libilitas yang sensitive terhadap bunga. Tujuan dari manajemen gap adalah : untuk menghindari kerugian yang diakibatkan oleh gejolak suku bunga dipasaran, mengusahakan pendapatan yang maksimal dalam batas resiko tertentu, menunjang manajemen likuiditas, mengelola resiko pada batas yang aman, dan menyusun struktur neraca yang mampu menghasilkan kinerja dan resiko yang wajar. Sasaran akhir dari manajemen likuiditas dan manajemen gap adalah penetapan suku bunga pinjaman.Tinggi rendahnya suku pinjaman sangat ditentukan oleh cost of money (terdiri atas cost of loanable fund ditambah overhead cost), resiko pembiayaan dan margin yang diharapkan.

Dari wawamcara dengan research partner, dapat direduksi dan analisis yang memberikan hasil sebagaimana yang disajikan bahwa : Penetapan suku bunga 
pinjaman hanya didasarkan pada kepraktisan/kebiasaan. Suku bunga pesaing dijadikan sebagai dasar penetapan suku bunga pinjaman, khususnya suku bunga BPR, Unit BRI dan KSP lain.

Dari temuan tersebut, patut diduga bahwa penetapan suku bunga yang dilakukan oleh pengelola KSP mengabaikan kajian sumber data internal yang dimiliki, tetapi lebih banyak didasarkan pada kelaziman yang berlaku dalam praktek sehari-hari.

\section{KESIMPULAN}

\begin{abstract}
Pengelolaan KSP yang ideal merupakan kemampuan manajer untuk menyeimbangkan kebutuhan dana dan menyalurkan dalam bentuk pinjaman kepada anggota atau calon anggota KSP yang bersangkutan. Dari kajian pendanaan terlihat bahwa KSP sepenuhnya tidak bisa mengandalkan penghimpunan dana yang berasal dari anggota, sehingga terpaksa mengandalkan sumber-sumber lain yang berasal dari non anggota, yang dilakukan dengan cara memanfaatkan celah peraturan yang ada.
\end{abstract}

Di luar cara tersebut, pengelola KSP pada umumnya kurang berminat untuk menjalin kemitraan dengan pihak Bank baik melalui lingkage program maupun program lainnya, hal ini dikarenakan adanya sebagian pandangan bahwa kerjasama tersebut lebih menguntungkan bagi pihak Bank. Selain itu, KSP juga belum siap untuk memenuhi kebutuhan dana jangka panjang dengan cara

\section{Daftar Pustaka}

Anisa Aini \& Achma Hendra Setiawan,2006

"Analisis Faktor yang

Mempengaruhi Partisipasi Anggota

KSU/USP Karyawan Pemda Kota

Semarang" Jurnal Dinamikan

Pembangunan Vol 3 No 2

Desember, 184-195

Bayu Krisnamurti. (2007) Membangun

Koperasi Berbasis Angota Dalam

RangkaPengembangan Ekonomi

Rakyat. menerbitkan obligasi/surat hutang yang disebabkan oleh kualitas SDM yang masih kurang memadai.

Seperti halnya dalam penghimpunan dana dan pemupukan modal, penyaluran dana dalam bentuk pinjaman, para pengelola KSP lebih cenderung untuk menyalurkan dananya kepada para calon anggota KSP dari pada anggota. Cara inipun ditempuh dengan memanfaatkan celah-celah peraturan. Berkaitan dengan upaya untuk menyimbangkan kebutuhan dana dan penyalurannya, pengelola KSP lebih banyak menggunakan pengalaman, sehingga kurang optimal dalam sumber dana dan berakibat terhadap tidak maskimalnya sisa hasil usaha. Lemahnya peraturan yang ada, membuat koperasi malakukan transformasi dan metamorphosis, sehingga dipergunakan dan dimanfaatkan oleh para pemburu untuk berperilaku seperti layaknya perbankan.

www.ekonomirakyat.org/edisi

4/artikel :

Burhanuddin, 2006. Evaluasi Program Bantuan Dana Bergulir Melalui KSP/USP,Jurnal Pengkajian Koperasi dan UKM, Nomor 1.

Dawam Raharjo, 1997, Koperasi Indonesia Menghadapi Abad ke21, Jakarta, DEKOPIN. Nurhayat Indra dkk. 2002. Ringkasan Studi Pengawasan KSP/USP dalam Rangka Otonomi Daerah di Jawa Barat. Kementrian Negara 
Koperasi dan UKM, Jakarta.

Edi Sunarko 2009 "Analisis Peran KSP/USP dalam Upaya Pengembangan UMKM di Kab Malang" Jurnal Modernisasi, Vol 5, No 3, Oktober, 2009

Ibrahim, Maulana. 2002. Strategi Pengembangan LKM Di Masa Mendatang. Lokakarya Lembaga Keuangan Mikro Agro Berbasis Information and Communication Technology (ICT) untuk Mendukung Pengembangan Usaha Mikro. Jakarta.

Jangkung Handoyo Mulyo (2007). Revitalisasi Ekonomi Kerakyatan Melali Pemberdayaan Gerakan Koperasi. http://io.ppijepang.org/article

Rini Gustifa \& Syukri, 2013, 'FaktorFaktor Yang Mempengaruhi Kredit Macet pada Koperai Simpan Pinjam di Kota Padang (Didasarkan Persepsi Anggota
Koperasi)" Jurnal fekon, Unand ac. id. Down load, tgl 20 Januari 2016

Subandi, Slamet, 2007. Kedudukan dan Kiprah Koperasi dalam Mendukung Pemberdayaan UMKM. Jurnal Pengkajian Koperasi dan UKM, Nomor 1.

Sugiharso,2009 "Sistem Ekonomi Kopersi

Sebagai Solusi Masalah
Perekonomian Indonesia, Mungkinkah?" Jurnal Ekonomi Pendidikan Volume 6, No 1, April, 2009

Sukijo, 2008 " Membangun Citra Koprasi Indonesia" Jurnal Ekonomi dan Pendidikan, Vol 5 No 2, Desember 2008

Sulaeman, Suhendar. 2004. Analisis Manfaat Lembaga Keuangan Berbentuk Koperasi (KSP/USP). Jurnal Ekonomi \& Bisnis. No. 2 